\title{
Polyphenolic compounds from Korean Lonicera japonica Thunb. induces apoptosis via AKT and caspase cascade activation in A549 cells
}

\author{
KWANG IL PARK ${ }^{1 *}$, HYEONSOO PARK $^{2 *}$, ARULKUMAR NAGAPPAN $^{3}$, GYEONG EUN HONG $^{3}$, \\ SILVIA YUMNAM ${ }^{3}$, HO JEONG LEE ${ }^{3}$, EUN HEE KIM ${ }^{4}$, WON SUP LEE ${ }^{5}$, SUNG CHUL SHIN ${ }^{6}$, \\ JIN A KIM ${ }^{7}$, SANG JOON LEE $^{8}$, JIN YEUL MA ${ }^{1}$, TAESUN MIN ${ }^{9}$, JEONG DOO HEO $^{8}$ and GON SUP KIM ${ }^{3}$
}

${ }^{1}$ Korean Medicine (KM)-Application Center, Korea Institute of Oriental Medicine (KIOM), Daegu, North Gyeongsang 41062;

${ }^{2}$ Daegu-Gyeongbuk Medical Innovation Foundation (DGMIF), Laboratory Animal Center, Daegu, North Gyeongsang 701-310;

${ }^{3}$ Research Institute of Life Science and College of Veterinary Medicine, Gyeongsang National University, Jinju, South Gyeongsang 660-701; ${ }^{4}$ Department of Nursing Science, International University of Korea, Jinju,

South Gyeongsang 660-759; ${ }^{5}$ Department of Internal Medicine, Institute of Health Sciences,

Gyeongsang National University School of Medicine, Gyeongnam Regional Cancer Center,

Gyeongsang National University Hospital, Jinju, South Gyeongsang 660-702; ${ }^{6}$ Department of Chemistry,

Research Institute of Life Science, Gyeongsang National University, Jinju, South Gyeongsang 660-701;

${ }^{7}$ Department of Physical Therapy, International University of Korea, Jinju, South Gyeongsang 660-759;

${ }^{8}$ Gyeongnam Department of Environment Toxicology and Chemistry, Toxicity Screening Research Center,

Korea Institute of Toxicology, Jinju, South Gyeongsang 52834;

${ }^{9}$ Department of Animal Biotechnology, Jeju National University, Jeju-do 690-756, Republic of Korea

Received July 8, 2015; Accepted September 6, 2016

DOI: $10.3892 / 01.2017 .5771$

\begin{abstract}
Lonicera japonica Thunb. (L. japonica T.) has historically been used in Korean herbal medicine due to its anticancer and protective effects on the respiratory system. In the present study, the polyphenolic compounds in L. japonica T. were investigated using high-performance liquid chromatography coupled with tandem mass spectrometry, and its anticancer effects on A549 non-small-cell lung cancer cells were studied.Polyphenolic compounds potentially inhibit A549 cells in a dose-dependent manner. Flow cytometry and western
\end{abstract}

Correspondence to: Professor Gon Sup Kim, Research Institute of Life Science and College of Veterinary Medicine, Gyeongsang National University, 900 Gajwadong, Jinju, South Gyeongsang 660-701, Republic of Korea

E-mail: gonskim@gnu.ac.kr

Dr Jeong Doo Heo, Gyeongnam Department of Environment Toxicology and Chemistry, Toxicity Screening Research Center, Korea Institute of Toxicology, 17 Jaegok Street, Jinju, South Gyeongsang 52834, Republic of Korea

E-mail: jdher@kitox.re.kr

*Contributed equally

Key words: anticancer, polyphenolic compounds, Lonicera japonica Thunb, protein kinase B, apoptosis blot analysis demonstrated that polyphenolic compounds induce apoptosis by regulating the protein expression levels of caspases, poly-(ADP-ribose) polymerase and the B-cell lymphoma-2-associated X-protein/B-cell lymphoma-extra large ratio. Furthermore, polyphenolic compounds inhibited mitochondrial membrane potential activity. Caspase-3 activity was increased in a dose-dependent manner and polyphenolic compounds inhibited the activation of protein kinase B by dephosphorylation. These results suggest that polyphenolic compounds in A549 cells indicate the anticancer activity through the induction of apoptosis.

\section{Introduction}

Lung cancer is the most common type of cancer worldwide and it is the leading cause of cancer-associated mortality in numerous countries (1). The majority (75-85\%) of lung cancers are non-small-cell lung cancers (NSCLC) $(2,3)$; NSCLC cells have malignant cell properties, including aggressive invasion and metastasis $(4,5)$. The most widely used treatments are chemotherapy, surgery, radiation therapy or a combination of these; however, recuperation and prognosis continue to be problematic (6). Although the survival rate for lung cancer is gradually increasing (7), novel therapeutic agents are required in order to increase the survival rates of patients with adenocarcinoma.

Lonicera japonica Thunb. (L. japonica T.; caprifoliaceae) has historically been used in East Asian countries, including 
Korea, China and Japan as an agent to treat fever, headache, upper respiratory tract infections, urinary disorders, rheumatoid arthritis and diabetes mellitus $(8,9)$. Previous studies have reported the mechanisms underlying the anti-inflammatory activity of L. japonica T. (10). Yip et al demonstrated that the aqueous compounds of L. japonica $T$. triggered HepG2 cell death in a c-Jun N-terminal kinase-dependent manner (11). A previous study has indicated that the polyphenolic compounds isolated from Korean $L$. japonica $T$. induced $\mathrm{G}_{2} / \mathrm{M}$ cell cycle arrest and apoptosis in HepG2 cells (12). In addition, luteoin and kaempferol, which are the major active constituents of $L$. japonica $T$., were observed to induce lung carcinoma cell apoptosis $(13,14)$. A previous study has also suggested that $L$. japonica $T$. protects cells from hydrogen peroxide-induced apoptosis through the phosphorylation of mitogen-activated protein kinases and phosphoinositide 3-kinase (PI3K)/protein kinase B (AKT) (15). However, the molecular mechanisms underlying the anticancer activity of $L$. japonica $T$. have yet to be elucidated; therefore, the current study used A549 cells to examine the therapeutic effects of the polyphenolic compounds.

Apoptosis has a crucial role in cell homeostasis and differs from cell necrosis (16). During apoptosis, the cells undergo morphological and biological changes, including nuclear fragmentation, cell shrinkage, chromatin condensation and DNA fragmentation (17). Apoptosis is regulated by the B-cell lymphoma-2 ( $\mathrm{Bcl}-2)$ protein family and also by certain caspases, which are a family of cysteine proteases (18). Apoptosis plays a pivotal role and prevents carcinogenesis by suppressing abnormal cell development or by removing mutated/damaged cells (19). Therefore, apoptosis is essential to the anticancer properties of numerous anticancer agents.

AKT has been observed to phosphorylate $>9,000$ proteins (20), thus, AKT is a critical regulator of cell growth, proliferation and cell death. AKT controls various signaling pathways, including the PI3K/AKT pathway and the apoptosis-associated proteins $\mathrm{Bcl}-2$-associated $\mathrm{X}$-protein (Bax), certain caspases and tumor protein-21 (p21), through the activation of downstream target proteins (21). The primary aim of the present study was to determine the effects of polyphenolic compounds on A549 cells in order to evaluate the anticancer potential of L. japonica $T$. The cytotoxicity of polyphenolic compounds was evaluated and cell apoptosis was determined using flow cytometry and immunoblotting for proteins specifically involved in apoptosis.

\section{Materials and methods}

Chemicals and reagents. RPMI-1640 was purchased from HyClone (GE Healthcare Life Sciences, Logan, UT, USA). Fetal bovine serum (FBS) and streptomycin/penicillin were purchased from Gibco (Thermo Fisher Scientific, Inc., Waltham, MA, USA). MTT, dimethyl sulfoxide (DMSO), propidium iodide (PI) and RNase A were obtained from Sigma-Aldrich (Merck Millipore, Darmstadt, Germany). Hoechst 33342 was purchased from Invitrogen (Thermo Fisher Scientific, Inc.). Anti-poly-(ADP-ribose) polymerase (PARP) (AB16661) and anti- $\beta$-actin (MAB1501) primary antibodies were obtained from EMD Millipore (Billerica, MA, USA). Anti-Bax (\#2772), anti-B-cell lymphoma-extra large (Bcl-xL)
(\#2764) and anti-caspase-3 (\#9662), -6 (\#9762), -8 (\#9764) and -9 (\#9508) antibodies were purchased from Cell Signaling Technology, Inc., (Danvers, MA, USA). Horseradish peroxidase-coupled goat anti-mouse (sc-2005) and rabbit (sc-2030) immunoglobulin (Ig)G and anti-rabbit $\mathrm{IgG}$ were purchased from Santa Cruz Biotechnology, Inc., (Dallas, TX, USA). The Fluorescein isothiocyanate (FITC) Annexin-V apoptosis detection kit 1 and carbocyanine dye $\mathrm{DiOC}_{6}$ were purchased from $\mathrm{BD}$ Biosciences (San Jose, CA, USA). The materials and chemicals (electrophoresis apparatus and electrophoresis buffer) used for electrophoresis were obtained from Bio-Rad Laboratories, Inc., (Hercules, CA, USA). An enhanced chemiluminescence kit was purchased from GE Healthcare Life Sciences (Chalfont, UK). All other chemicals, including glycine, trizma, sodium chloride and sodium dodecyl sulfate, were of the purest grade available and purchased from Sigma-Aldrich (Merck Millipore).

Purification and isolation of polyphenol components of L. japonica $T$. Purification and isolation of polyphenol components of $L$. japonica $T$. was performed according to a previously described method (22). L. japonica $T$. was obtained from the Animal Bio-Resources Bank (Jinju, Korea). The voucher specimen (\#00101B) was deposited at the Animal Bio Resources Bank, Gyeongsang National University subsequent to purification in the present study. The lyophilized plant material (100 g) was ground into a powder and added to $500 \mathrm{ml}$ of $70 \%$ methanol at $50^{\circ} \mathrm{C}$ for $12 \mathrm{~h}$. The material was filtered using a Büchner funnel, and concentrated to $\sim 100 \mathrm{ml}$ at $40^{\circ} \mathrm{C}$ using a rotary evaporator. The residue was reconstituted in $0.01 \mathrm{~g} / \mathrm{ml}$, methanol and stored at $-20^{\circ} \mathrm{C}$ until analysis. The mixtures of polyphenolic compounds were reconstituted in methanol $(0.01 \mathrm{~g} / \mathrm{ml})$, filtered through $0.45-\mu \mathrm{m}$ cellulose membranes, transferred into silicanized vials and stored at $-20^{\circ} \mathrm{C}$ prior to high-performance liquid chromatography (HPLC) analysis. HPLC was conducted using an Agilent 1100 series LC system (Agilent Technologies, Inc., Santa Clara, CA, USA). Chromatographic separation was performed on a Zorbax stable bond analytical SB-C ${ }_{18}$ column $(4.6 \times 250 \mathrm{~mm} ; 5 \mu \mathrm{m}$; Agilent Technologies, Inc.). The flow rate was $0.5 \mathrm{ml} / \mathrm{min}$, with the column temperature maintained at $30^{\circ} \mathrm{C}$ and an injection volume of $10 \mathrm{ml}$ in each experiment. PAD spectra were measured over a wavelength range of 240-600 nm in $2 \mathrm{~min}$ steps. Tandem mass spectrometry (MS/MS) experiments were conducted on a 3200 Q TRAP LC-MS/MS system (Applied Biosystems; Thermo Fisher Scientific, Inc.) with a Turbo $\mathrm{V}^{\mathrm{TM}}$ source and a turbo ion spray probe operation, at $450^{\circ} \mathrm{C}$.

Cell culture and treatment. A549 human lung carcinoma cells were obtained from the Korean Cell Line Bank (Seoul, Korea) and were cultured in RPMI-1640 medium supplemented with $10 \%$ FBS and $1 \%$ penicillin/streptomycin in an atmosphere containing $5 \% \mathrm{CO}_{2}$ at $37^{\circ} \mathrm{C}$. The cells were grown to $70-80 \%$ confluency, and then treated with $0,200,400,800,1,200$, or $1,500 \mu \mathrm{g} / \mathrm{ml}$ polyphenolic compounds (Table I) dissolved in $1 \%$ DMSO for $24 \mathrm{~h}$ in the complete growth medium (RPMI-1640 medium with 10\% FBS and 1\% antibiotics; Gibco; Thermo Fisher Scientific, Inc.).

Cytotoxicity assay. An MTT assay was performed to determine the cytotoxicity of the polyphenolic compounds in A549 cells. 
Table I. The retention time of identified polyphenolic compounds isolated from Korean L. japonica T.

\begin{tabular}{|c|c|c|c|c|}
\hline No. & Compound & Rt (min) & MS(M-H)- & $\mathrm{MS} / \mathrm{MS}$ \\
\hline 1 & Caffeoylquinic acid dimer & 17.20 & 707 (708) & $353,191,179,161,127$ \\
\hline 2 & Caffeoylquinic acid & 18.09 & $353(354)$ & $337,191,179,135$ \\
\hline $3+4$ & $\begin{array}{l}\text { Caffeoylglycerol + 5-p- } \\
\text { coumaroylquinic acid }\end{array}$ & $\begin{array}{l}22.55 \\
22.55\end{array}$ & $\begin{array}{l}253(254) \\
337(338)\end{array}$ & $253,179,161,135,133$ \\
\hline 5 & Feruloylquinic acid & 28.78 & $\begin{array}{l}367(368)- \\
369(368)+\end{array}$ & $\begin{array}{l}368 / 367,179,161,135,369 \\
163,145,135,117\end{array}$ \\
\hline 6 & Dicaffeoylquinic acid & 34.49 & $515(516)$ & $\begin{array}{l}515,353,335,191,179,173, \\
161,155,135,111\end{array}$ \\
\hline 7 & Dicaffeoylquinic acid & 35.37 & $515(516)$ & $353,191,179,173,161,135$ \\
\hline 8 & Kaempferol 3-O-glucoside & 39.43 & $\begin{array}{c}447(448) \\
449(448)+\end{array}$ & $\begin{array}{l}447,285 \\
449,287\end{array}$ \\
\hline 9 & Kaempferol- $O$-rutinoside & 40.99 & $595[\mathrm{M}+\mathrm{H}]-$ & $449,287,269,241,153,135,105$ \\
\hline 10 & Dicaffeoylquinic acid & 41.95 & $515(516)$ & $\begin{array}{l}515,353,335,191,179,173 \\
161,155,135,111\end{array}$ \\
\hline 11 & Apigenin-7-O-glucoside & 46.63 & $\begin{array}{l}431(432)- \\
433(432)+\end{array}$ & $\begin{array}{l}432 / 431,269 \\
433,271\end{array}$ \\
\hline $12+13$ & $\begin{array}{l}\text { Apigenin rutinoside }+ \\
\text { Feruoyl caffeoylquinic acid }\end{array}$ & $\begin{array}{l}47.47 \\
47.47\end{array}$ & $\begin{array}{c}579(578)+ \\
529(530)\end{array}$ & $579,433,287,271,153$ \\
\hline 14 & Trihydroxymethoxyflavone & 49.19 & 299 & 299,284 \\
\hline $15+16$ & $\begin{array}{l}\text { Kaempferol } \\
\text { + Isorhamnetin glucoside }\end{array}$ & $\begin{array}{l}50.28 \\
50.28\end{array}$ & $\begin{array}{c}287(286)+ \\
477(478)\end{array}$ & $\begin{array}{l}287,269,153,137,119,477, \\
357,314,299,285,271,257,243\end{array}$ \\
\hline 17 & Caffeic acid derivative & 53.07 & $537(538)$ & $537,375,331,179,161,151,135$ \\
\hline 18 & Feruoyl caffeoylquinic acid & 55.71 & $529(530)$ & $529,367,349,179,161,135$ \\
\hline
\end{tabular}

L. japonica T., Lonicera japonica Thunb.; Rt, retention time; MS(M-H)-; MS/MS., tandem mass-spectrometry.

Cells were seeded in a 12 -well plate at a density of $1 \times 10^{5}$ cells $/ \mathrm{ml}$ and incubated for $24 \mathrm{~h}$ at $37^{\circ} \mathrm{C}$ in a $5 \% \mathrm{CO}_{2}$ atmosphere. The cells were treated with various concentrations of polyphenolic compounds $(0,200,400,800,1,200$ or $1,500 \mu \mathrm{g} / \mathrm{ml})$ for $4 \mathrm{~h}$ at $37^{\circ} \mathrm{C}$ in a $5 \% \mathrm{CO}_{2}$ atmosphere. Following incubation, $100 \mu \mathrm{l}$ MTT solution [5 $\mathrm{mg} / \mathrm{ml}$ in phosphate buffered saline (PBS)] was added to each well and the cells were incubated for $3 \mathrm{~h}$ at $37^{\circ} \mathrm{C}$ in a $5 \% \mathrm{CO}_{2}$ atmosphere. Subsequently, $500 \mu 1 \mathrm{DMSO}$ was added to each well, following the complete removal of the medium, in order to dissolve the formazan crystals. The optical density (OD) of the cells at $540 \mathrm{~nm}$ was determined using a SpectraMax i3 microplate reader (Molecular Devices, Sunnyvale, CA, USA).

Nuclear morphology. Variations in cell morphology were analyzed using light and fluorescence microscopy. A549 cells treated with polyphenolic compounds were centrifuged at $300 \times \mathrm{g}$ for $5 \mathrm{~min}$ at room temperature, fixed for $15 \mathrm{~min}$ in PBS containing $4 \%$ paraformaldehyde, washed with PBS and then stained with Hoechst $33342(20 \mu \mathrm{g} / \mathrm{ml})$ for $10 \mathrm{~min}$. The nuclear morphology was imaged using a Leica DM6000 B fluorescence microscope (Leica Microsystems, Inc., Buffalo Grove, IL, USA) with a $350 \mathrm{~nm}$ excitation wavelength (blue fluorescence).

Cell cycle analysis. Flow cytometry was performed to analyze the distribution of the cell cycle. The A549 cells $\left(6.0 \times 10^{5}\right.$ cells/well; 6 well plate) were treated with polyphenolic compounds $(0,200,400,800$ and 1,200 $\mu \mathrm{g} / \mathrm{ml})$ and incubated for $24 \mathrm{~h}$ at $37^{\circ} \mathrm{C}$ in a $5 \% \mathrm{CO}_{2}$ atmosphere. Cells were then trypsinized, washed twice with cold phosphate-buffered saline (PBS) and centrifuged $300 \times \mathrm{g}$ for $5 \mathrm{~min}$ at room temperature. The pellet was fixed with cold $70 \%$ (v/v) ethanol for $30 \mathrm{~h}$ at $4^{\circ} \mathrm{C}$. The cells were washed once with PBS and resuspended in cold PI $(50 \mu \mathrm{g} / \mathrm{ml})$, containing RNase A $(0.1 \mathrm{mg} / \mathrm{ml})$ in PBS (pH 7.4), for $30 \mathrm{~min}$ in the dark. The cellular DNA content was analyzed by flow cytometry using a FACS Calibur apparatus (BD Biosciences). Forward light scatter characteristics were used to exclude cell debris from the analysis and $\geq 1 \times 10^{4}$ cells were used for each analysis. Cell cycle distribution was analyzed using the ModFit LT program (Verity Software House, Topsham, ME, USA) and the relative proportions of cells in the $G_{0} / G_{1}, S$ and $G_{2} / M$ phases were determined for the cell cycle analysis.

Annexin V-FITC/PI double staining assay. A549 cells $\left(6.0 \times 10^{5}\right.$ cells/well; 6 well plate) were harvested using trypsin following treatment for $24 \mathrm{~h}$ with polyphenolic compounds $(0,200,400$, 800 and $1,200 \mu \mathrm{g} / \mathrm{ml}$ ), and the magnitude of apoptosis was determined using the FITC-Annexin-V apoptosis detection kit 1 , according to the manufacturer's instructions. Briefly, the cells were washed with ice-cold PBS and resuspended in $100 \mu \mathrm{l}$ Annexin-V binding buffer containing $10 \mathrm{mM}$ HEPES/NaOH 
(pH 7.4), $140 \mathrm{mM} \mathrm{NaCl}$ and $2.5 \mathrm{mMCaCl}_{2}$. Aliquots of the cells were incubated in $5 \mu \mathrm{l}$ an Annexin V-FITC solution and $5 \mu \mathrm{l}$ $\mathrm{PI}$ at room temperature for $15 \mathrm{~min}$ in the dark. Subsequently, $400 \mu l$ binding buffer was added and the apoptotic cells were evaluated using fluorescence-activated cell sorter analysis in a flow cytometer.

Measurement of mitochondrial membrane potential (MMP). Flow cytometry was performed to analyze the MMP in A549 cells using the carbocyanine dye $\mathrm{DiOC}_{6}$. Briefly, A549 cells $\left(6.0 \times 10^{5}\right.$ cells/well) were treated with polyphenolic compounds $(0,200,400,800$ and $1,200 \mu \mathrm{g} / \mathrm{ml})$ and incubated for $24 \mathrm{~h}$ at $37^{\circ} \mathrm{C}$ in a $5 \% \mathrm{CO}_{2}$ atmosphere The cells were trypsinized, washed in PBS and then incubated with $\mathrm{DiOC}_{6}(40 \mathrm{nM})$ at $37^{\circ} \mathrm{C}$ for $15 \mathrm{~min}$ in the dark. The cells were analyzed immediately with a flow cytometer.

Western blot analysis. Western blot analysis was conducted according to a previously described method (23). A549 cells $\left(6.0 \times 10^{5}\right.$ cells/well) were cultured in 6-well plates and incubated for $24 \mathrm{~h}$ with various concentrations of polyphenolic compounds $(0,200,400,800$ and $1,200 \mu \mathrm{g} / \mathrm{ml})$ or with DMSO as a solvent control. Following washing with ice cold PBS, the cells were lysed by RIPA buffer, and a Bradford assay (Bio-Rad Laboratories, Inc.) was used to determine the protein concentration. An equal amount of protein $(20 \mu \mathrm{g})$ was loaded into each well and subjected to $12 \%$ SDS-PAGE $(90 \mathrm{~V}$ for $4 \mathrm{~h}$ at $4^{\circ} \mathrm{C}$ ) and the resolved proteins were transferred to a $0.45 \mathrm{~mm}$ immunobilon polyvinyldene fluoride membrane (EMD Millipore). The membranes were probed with the aforementioned primary antibodies (dilution, 1:1,000) overnight at $4^{\circ} \mathrm{C}$, and then incubated with the aforementioned secondary antibody (dilution, 1:2,000) for $2 \mathrm{~h}$ at room temperature. The membranes were visualized by enhanced chemiluminescence and western blotting detection reagents (GE Healthcare Life Sciences) and exposed to x-ray film (Fuji, Tokyo, Japan). Band expression levels were quantified using ImageJ (version 1.49v for Windows; National Institutes of Health, Bethesda, MD, USA). The densitometry readings of the bands were normalized to $\beta$-actin expression.

Caspase-3 activity assay. Caspase-3 activity analysis was measured according to a previously described method (23). Caspase- 3 activity was evaluated by the detection of the cleavage of $\mathrm{N}$-acetyl-Asp-Glu-Val-Asp-p-nitroaniline, a colorimetric caspase-3 substrate, using a caspase-3 activity assay kit (APT165; EMD Millipore), according to the manufacturer's instructions. Briefly, A549 cells were treated with polyphenolic compounds for $24 \mathrm{~h}$. The floating and adherent cells were collected and lysed in ice-cold RIPA buffer for $30 \mathrm{~min}$ in an ice bath. The supernatants were collected and incubated at $37^{\circ} \mathrm{C}$ for $2-4 \mathrm{~h}$ with the reaction buffer (EMD Millipore), according to the manufacturer's instructions. The OD of the protein samples was evaluated at $405 \mathrm{~nm}$ with a SpectraMax i3 microplate reader (Molecular Devices, Sunnyvale, CA, USA).

Statistical analysis. The data are presented as the mean \pm standard deviation of three independent experiments. The data were analyzed with a Student's $t$-test and one-way analysis of variance with a post-hoc Tukey test, using SPSS version 10.0 for Windows (SPSS, Inc., Chicago, IL, USA). P $<0.05$ was considered to indicate a statistically significant result.

\section{Results}

Characterization of polyphenolic compounds in L. japonica T. The polyphenol components of $L$. japonica $T$. were isolated using HPLC. The 18 polyphenol components isolated were characterized using HPLC, mass spectra and data from the literature. The HPLC chromatogram and mass data were summarized in Fig. 1 and Table I, respectively (24).

Cell growth inhibition by polyphenolic compounds. To evaluate the effect of cell viability inhibition, the cytotoxicity of various concentrations of polyphenolic compounds $(0-1,500 \mu \mathrm{g} / \mathrm{ml})$ in A549 cells was examined using an MTT assay. As indicated in Fig. 1B, polyphenolic compounds inhibited the viability of A549 cells, as compared with the control cells (vehicle only), in a dose-dependent manner following a $24 \mathrm{~h}$ treatment ( $\mathrm{P}=0.0018$ for $200 \mu \mathrm{g} / \mathrm{ml}, \mathrm{P}=0.026$ for $400 \mu \mathrm{g} / \mathrm{ml}, \mathrm{P}=0.0011$ for $800 \mu \mathrm{g} / \mathrm{ml}, \mathrm{P}<0.0001$ for $1,200 \mu \mathrm{g} / \mathrm{ml}$ and $\mathrm{P}<0.0001$ for $1,500 \mu \mathrm{g} / \mathrm{ml})$. Polyphenolic compounds decreased cell growth by $\sim 38 \%$ at $1,200 \mu \mathrm{g} / \mathrm{ml}$. The $50 \%$ inhibitory concentration (IC50) was determined to be $\sim 1,140 \mu \mathrm{g} / \mathrm{ml}$. Cell viability was not significantly changed by the application of various concentrations of polyphenolic compounds in a normal cell line, a human embryonic fibroblast cell line or the WI-38 lung-derived cell line (data not presented). These results suggest that the extracted polyphenolic compounds had an anti-proliferative effect in A549 cells.

Polyphenolic compounds increase the proportion of cells in the sub-G $G_{1}$ phase in A549 cells. Flow cytometry was used to investigate the distribution of A549 cell cycle phases following treatment with polyphenolic compounds at various concentrations $(0,200,400,800$ and $1,200 \mu \mathrm{g} / \mathrm{ml})$ for $24 \mathrm{~h}$. As presented in Fig. 2A, the polyphenolic compounds significantly increased the proportion of A549 cells in a sub- $\mathrm{G}_{1}$ phase of 14.9 and $35.7 \%$ $(\mathrm{P}=0.0414$ and $\mathrm{P}<0.0001)$ at 800 and $1,200 \mu \mathrm{g} / \mathrm{ml}$, respectively compared with the control (5.3\%), whereas the proportion of cells in the $\mathrm{G}_{1}, \mathrm{~S}$, and $\mathrm{G}_{2} / \mathrm{M}$ phases were decreased in a dose-dependent manner $(\mathrm{P}=0.038$ for $800 \mu \mathrm{g} / \mathrm{ml}$ and $\mathrm{P}<0.0001$ for $1,200 \mu \mathrm{g} / \mathrm{ml}$ in $\mathrm{G} 1$ phase; $\mathrm{P}=0.0059$ for $400 \mu \mathrm{g} / \mathrm{ml}$, $\mathrm{P}=0.0015$ for $800 \mu \mathrm{g} / \mathrm{ml}$ and $\mathrm{P}=0.0018$ for $1,200 \mu \mathrm{g} / \mathrm{ml}$ in $\mathrm{S}$ phase; $\mathrm{P}=0.0044$ for $1,200 \mu \mathrm{g} / \mathrm{ml}$ in $\mathrm{G} 2 / \mathrm{M}$ phase). The data presented in Fig. 2B indicate the prevalence of the cell cycle phases at each concentration of the polyphenolic compounds used. These results suggest that polyphenolic compounds are able to induce apoptosis in A549 cells.

Polyphenolic compounds induce apoptosis in A549 cells. PI and Annexin V-FITC/PI double-labeled flow cytometry was used to analyze the rate of apoptosis in A549 cells treated with various concentrations of polyphenolic compounds for $24 \mathrm{~h}$. The treated A549 cells demonstrated that the proportion of cells that underwent early apoptosis (lower right quadrant) was $51.5 \%$ at $800 \mu \mathrm{g} / \mathrm{ml}$ polyphenol, whereas the early apoptotic cell proportion was $21.1 \%$ at $1,200 \mu \mathrm{g} / \mathrm{ml}$ polyphenol. The late apoptotic cell proportions (upper right quadrant) were 8.3 
A

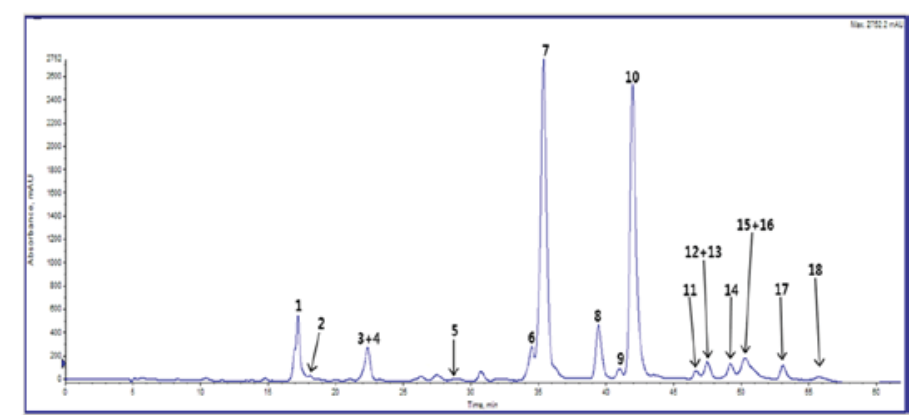

B

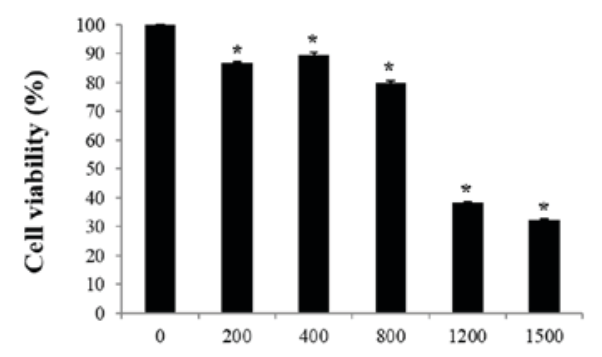

Polyphenols $(\mu \mathrm{g} / \mathrm{ml})$

Figure 1. Characterization of polyphenolic compounds identified from Korean L. japonica T. in A549 cells. (A) HPLC profiles of Korean L. japonica T. at 280 nm: (1) Caffeoylquinic acid dimer; (2) Caffeoylquinic acid; (3) Caffeoylglycerol; (4) 5-p-coumaroylquinic acid; (5) Feruloylquinic acid; (6) Dicaffeoylquinic acid; (7) Dicaffeoylquinic acid; (8) Kaempferol 3-O-glucoside; (9) Kaempferol- $O$-rutinoside; (10) Dicaffeoylquinic acid; (11) Apigenin-7-O-glucoside; (12) Apigenin rutinoside; (13) Feruoyl caffeoylquinic acid; (14) Trihydroxymethoxyflavone; (15) Kaempferol; (16) Isorhamnetin glucoside; (17) Caffeic acid derivative; and (18) Feruoyl caffeoylquinic acid. (B) Growth inhibition of A549 cells following treatment with various concentrations $(0-1,500 \mu \mathrm{g} / \mathrm{ml})$ of polyphenolic compounds for $24 \mathrm{~h}$. "P<0.05 compared with the control. HPLC, high performance liquid chromatography; L. japonica T., Lonicera japonica Thunb.

A

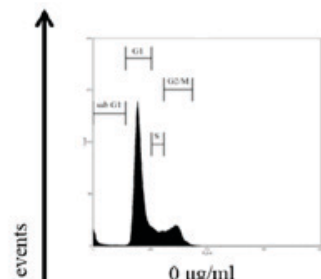

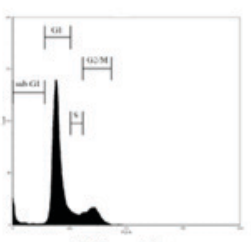

$100 \mu \mathrm{g} / \mathrm{ml}$

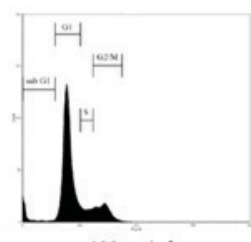

$400 \mu \mathrm{g} / \mathrm{ml}$

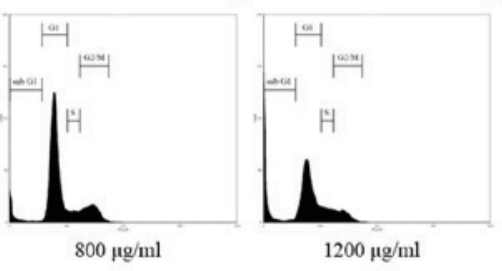

Channels (FL2-A)

B

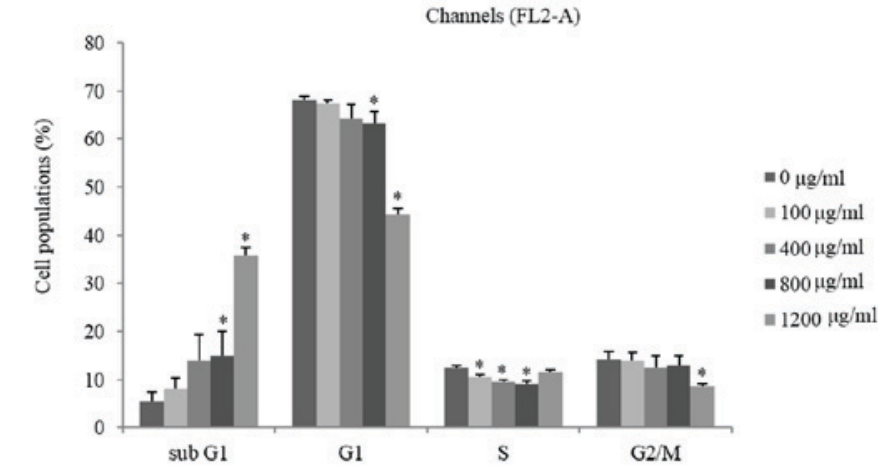

Figure 2. Effect of polyphenolic compounds on the cell cycle distribution in A549 cells. The cells were incubated with various concentrations $(0-1,200 \mu \mathrm{g} / \mathrm{ml})$ of polyphenolic compounds for $24 \mathrm{~h}$ and the distribution of the cell cycle was evaluated using FACS analysis. (A) Flow cytometry of cell cycle phase distribution; (B) statistical analysis of cell cycle phase distribution. The data are presented as the mean \pm standard deviation of triplicate independent experiments. ${ }^{*} \mathrm{P}<0.05$ compared with the control. 


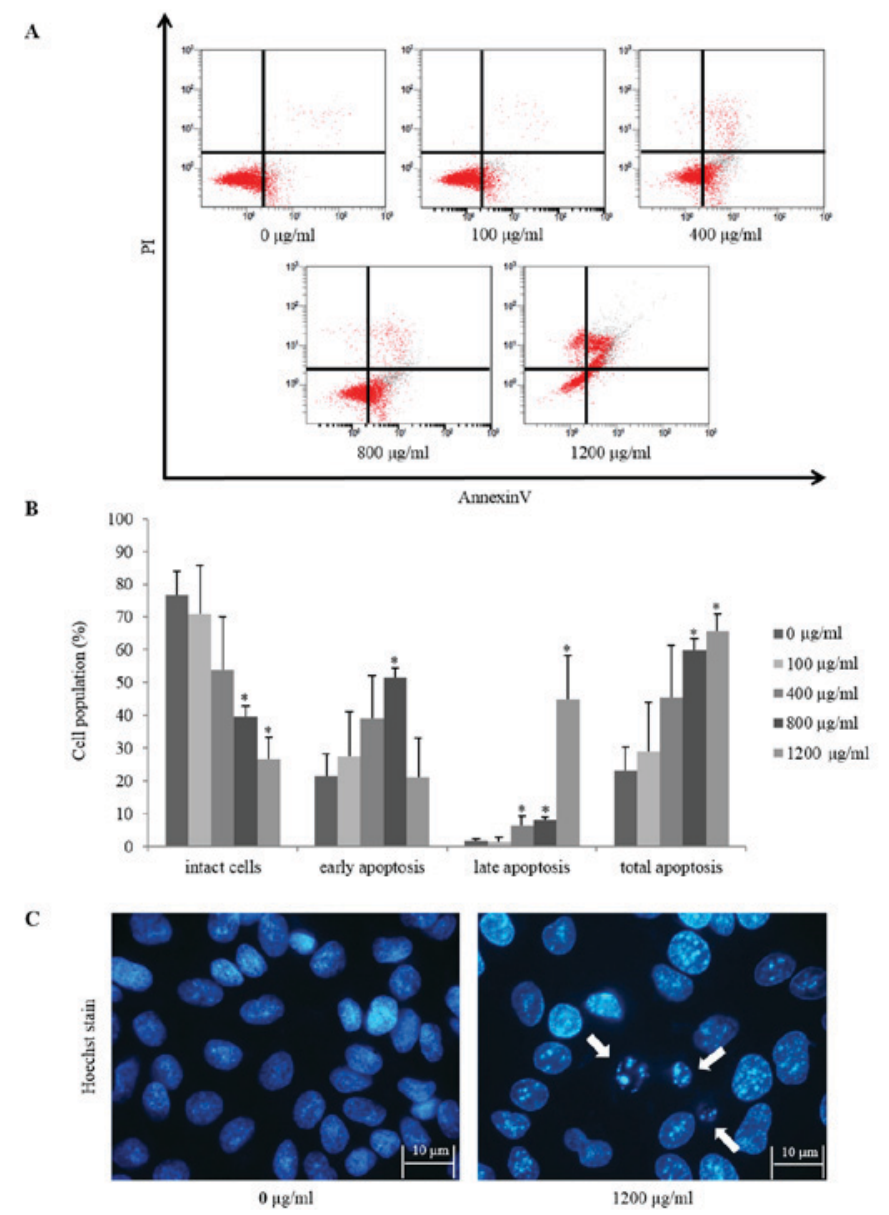

Figure 3. Induction of apoptosis in A549 cells by flavonoids. The apoptosis ratio was detected by Annexin V-FITC/PI double staining. (A) Flow cytometry analysis, (B) statistical analysis for apoptosis detection, (C) the cells were incubated with flavonoids for $24 \mathrm{~h}$, fixed and stained with Hoechst 33342 . The cells were imaged using a Leica DM6000 B microscope (magnification, 400x). The white arrows indicate chromatin condensation. The data are presented as the mean \pm standard deviation of triplicate independent experiments. " $\mathrm{P}<0.05$ compared with the control. FITC, fluorescein isothiocyanate; PI, propidium iodide.

and $44.8 \%$ at 800 and $1,200 \mu \mathrm{g} / \mathrm{ml}$ polyphenol, respectively. The total apoptotic cell proportion was significantly 59.8 and $65.9 \%$ at $800(\mathrm{P}=0.0014)$ and $1,200 \mu \mathrm{g} / \mathrm{ml}(\mathrm{P}=0.0011)$, respectively (Fig. 3A and B). Furthermore, the A549 cells treated with polyphenolic compounds at $1,200 \mu \mathrm{g} / \mathrm{ml}$ demonstrated changes in apoptotic features, including nuclear fragmentation and chromatin condensation, which were observed following staining with Hoechest 33342 (Fig. 3C). The results indicate that polyphenolic compounds induce apoptosis in A549 cells.

The effect of polyphenolic compounds on the mitochondrial stability of A549 cells. To further investigate the features of polyphenolic compound-induced apoptosis in A549 cells, the MMP of the A549 cells was detected. Fig. 4A and B demonstrates that $1,200 \mu \mathrm{g} / \mathrm{ml}$ of the polyphenolic compounds induced significant mitochondrial disruption in $18.4 \%$ of the cells following a $24 \mathrm{~h}$ incubation compared with the control $(\mathrm{P}<0.0001)$. The results suggest that the polyphenolic compounds disrupt the MMP, which then triggers the activation and cleavage of certain caspases and the subsequent cell apoptosis.

Polyphenolic compounds induce Bcl-2 family proteins and caspase activation in A549 cells. Following treatment with polyphenolic compounds in A549 cells, Bcl-xL expression levels were decreased 3 -fold in a dose-dependent manner $(\mathrm{P}=0.0232$ for $400 \mu \mathrm{g} / \mathrm{ml}, \mathrm{P}=0.0021$ for $800 \mu \mathrm{g} / \mathrm{ml}$ and $\mathrm{P}=0.0001$ for $1,200 \mu \mathrm{g} / \mathrm{ml})$, whereas Bax expression levels were increased $\sim 5$-fold compared with the control $(\mathrm{P}=0.0243$ for $1,200 \mu \mathrm{g} / \mathrm{ml})$. A densitometric analysis of the western blotting bands revealed that treatment of A549 cells with polyphenolic compounds increased the $\mathrm{Bax} / \mathrm{Bcl}-\mathrm{xL}$ ratio in a dose-dependent manner ( $\mathrm{P}<0.0001$ for $1,200 \mu \mathrm{g} / \mathrm{ml}$ ) (Fig. 5A). In addition, poly phenolic compounds decreased the expression levels of pro-caspases-3 ( $\mathrm{P}=0.0042$ for $400 \mu \mathrm{g} / \mathrm{ml}, \mathrm{P}=0.0019$ for $800 \mu \mathrm{g} / \mathrm{ml}$ and $\mathrm{P}=0.0006$ for $1,200 \mu \mathrm{g} / \mathrm{ml}),-6(\mathrm{P}=0.0432$ for $400 \mu \mathrm{g} / \mathrm{ml}, \mathrm{P}=0.0219$ for $800 \mu \mathrm{g} / \mathrm{ml}$ and $\mathrm{P}=0.0012$ for $1,200 \mu \mathrm{g} / \mathrm{ml}),-8(\mathrm{P}=0.0046$ for $400 \mu \mathrm{g} / \mathrm{ml}, \mathrm{P}=0.0029$ for $800 \mu \mathrm{g} / \mathrm{ml}$ and $\mathrm{P}=0.0097$ for $1,200 \mu \mathrm{g} / \mathrm{ml})$ and $-9(\mathrm{P}=0.0003$ for $400 \mu \mathrm{g} / \mathrm{ml}, \mathrm{P}=0.0016$ for $800 \mu \mathrm{g} / \mathrm{ml}$ and $\mathrm{P}=0.0004$ for $1,200 \mu \mathrm{g} / \mathrm{ml})$, decreased the expression levels of PARP $(\mathrm{P}=0.0016$ for $100 \mu \mathrm{g} / \mathrm{ml} \mathrm{P}=0.0011$ for $400 \mu \mathrm{g} / \mathrm{ml}, \mathrm{P}=0.0026$ for $800 \mu \mathrm{g} / \mathrm{ml}$ and $\mathrm{P}=0.0001$ for $1,200 \mu \mathrm{g} / \mathrm{ml})$ and increased caspase- 3 activity in a dose-dependent manner $(\mathrm{P}=0.035$ for $100 \mu \mathrm{g} / \mathrm{ml}, \mathrm{P}=0.027$ for $400 \mu \mathrm{g} / \mathrm{ml}, \mathrm{P}=0.004$ for $800 \mu \mathrm{g} / \mathrm{ml}$ and $\mathrm{P}=0.001$ for $1,200 \mu \mathrm{g} / \mathrm{ml}$ ) (Fig. 5B). These results suggest that polyphenolic compounds-induce apoptosis by increasing the $\mathrm{Bax} / \mathrm{Bcl}-\mathrm{xL}$ ratio and activating certain caspases. 


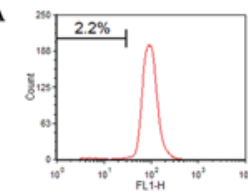

$0 \mu \mathrm{g} / \mathrm{m}$
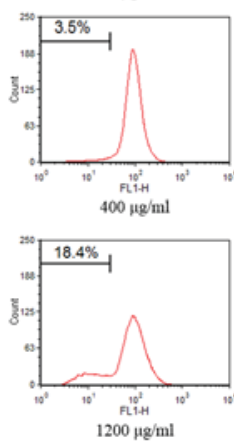

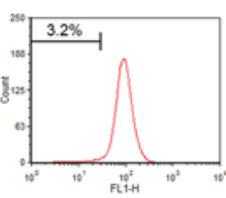

$100 \mu \mathrm{g} / \mathrm{ml}$

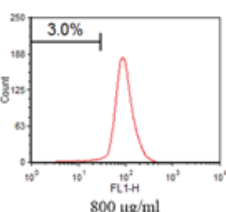

$800 \mu \mathrm{g} / \mathrm{ml}$

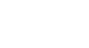

B

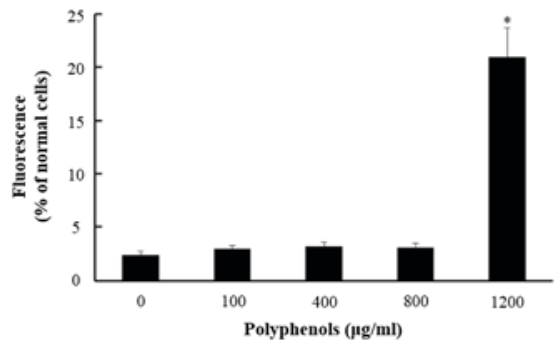

Figure 4. Polyphenolic compounds induced mitochondrial membrane potential stability. Cells were treated with various concentrations of polyphenolic compounds $(0-1,200 \mu \mathrm{g} / \mathrm{ml})$ for $24 \mathrm{~h}$. (A) The cells were stained with the carbocyanine dye DiOC 6 and flow cytometry was performed to determine the MMP stability. (B) Fluorescence light was detected by flow cytometry and expressed as a bar graph. The data are presented as the mean \pm standard deviation of triplicate independent experiments. " $\mathrm{P}<0.05$ compared with the control. MMP, mitochondrial membrane potential.

Polyphenolic compounds decrease p-AKT in A549 cells. To determine the effect of polyphenolic compounds on the expression levels of phosphorylated (P)-AKT in A549 cells, western blot analysis was performed on those cells treated with polyphenolic compounds for $24 \mathrm{~h}$. As presented in Fig. 5C, the expression levels of $\mathrm{p}$-AKT in treated cells were decreased in a dose-dependent manner $(\mathrm{P}=0.0211$ for $400 \mu \mathrm{g} / \mathrm{ml}, \mathrm{P}=0.0165$ for $800 \mu \mathrm{g} / \mathrm{ml}$ and $\mathrm{P}=0.0005$ for $1,200 \mu \mathrm{g} / \mathrm{ml}$ ). However, the total level of AKT expressed did not differ, revealing that polyphenolic compounds dephosphorylate AKT in A549 cells.

\section{Discussion}

Plant-derived herbal medicines have historically been used as traditional treatments in certain Asian countries, including Korea and China (25). Over half of the anticancer drugs identified originated from plants and a number of studies have been conducted on cancer prevention through the use of dietary polyphenolic compounds (10). Numerous studies have successfully demonstrated that naturally occurring dietary polyphenolic compounds have antiproliferative properties and, therefore, these compounds are considered to have anticancer effects (26). In the present study, the anticancer properties of the polyphenolic compounds isolated from L.japonica $T$. were investigated in A549 cells.

The regulation of apoptosis is essential for the maintenance of cell homeostasis. Apoptotic signals are regulated primarily by caspases, which perform as inactive zymogens in cells and produce a cascade of catalytic effects when apoptosis is initiated (27). Numerous studies have aimed to elucidate the mechanisms underlying the caspase signaling pathway mediated cell apoptosis (16). Following stimulation by natural killer T-cells, caspase-3 activation triggers multiple signaling cascades, and this cascade reaction acts to stimulate mitochondria to release cytochrome c. An excess of cytochrome $c$ recruits caspase- 9 for the activation of caspase-3 (28). It was previously determined that kaempferol was able to induce apoptosis in pancreatic cancer cells through DNA damage (29). In the current study the expression levels of pro-caspase $-3,-6,-8$ and -9 were significantly downregulated. Furthermore, the upregulation of caspase- 3 activity indicates that polyphenolic compound-induced apoptosis is dependent on caspase-3. The $\mathrm{Bcl}$ family also has an important role in cell apoptosis. The $\mathrm{Bcl}$ proteins are apoptotic regulatory proteins that control the mitochondrial apoptotic process (30). Bcl-xL interacts with the mitochondrial plasma membrane to inhibit the other apoptotic factors, including Bax and Bak. This prevents induced cytochrome $c$ from interacting with the mitochondrial plasma membrane. Furthermore, kaempferol is able to induce apoptosis in specific ovarian cancer cell lines by the inhibition of $\mathrm{Bcl}$ proteins expression (31). The Bax/Bcl-xL ratio may be a key mechanism underlying apoptosis as the results demonstrate that the $\mathrm{Bax} / \mathrm{Bcl}-\mathrm{xL}$ ratio was increased in the A549 cells treated with polyphenolic compounds.

Mitochondria power eukaryotic cells and MMP has become a frequently used tool for monitoring changes in the cells; therefore, MMP is a key indicator of cell health or injury. During cellular stress, MMP may be altered by the dysregulation of intracellular ionic charges, including $\mathrm{Ca}^{2+}$ and $\mathrm{K}^{+}$, thus leading to a failure in adenosine triphosphate production and the collapse of cell homeostasis (32). The current study evaluated MMP in A549 cells using DiOC $_{6}$ fluorescence dye. Treatment of the cells with polyphenolic compounds at $1,200 \mu \mathrm{g} / \mathrm{ml}$ significantly increased MMP, compared with the control. The results indicate that polyphenol induces apoptosis through a mitochondria-dependent signaling pathway in A549 cells.

AKT is a serine/threonine protein kinase that serves as a pivotal regulator of diverse cellular responses (21). The AKT signaling pathway is one of the most important signaling pathways in various types of human cancer; AKT is typically overexpressed in human cancers (33). Previous studies have identified that the inhibition of AKT induces apoptosis or cell 


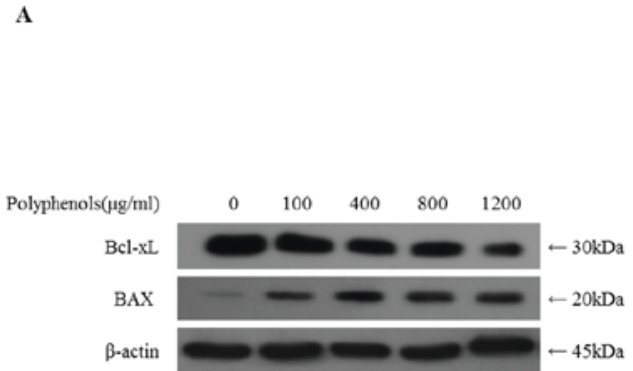

B

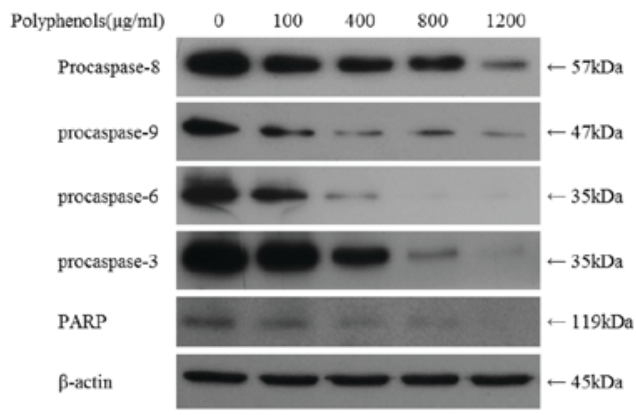

C

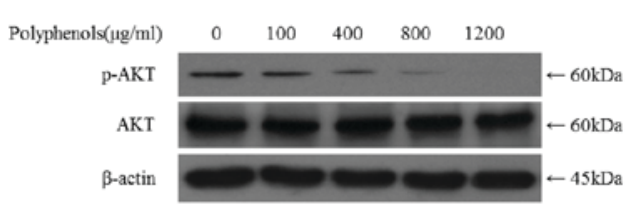

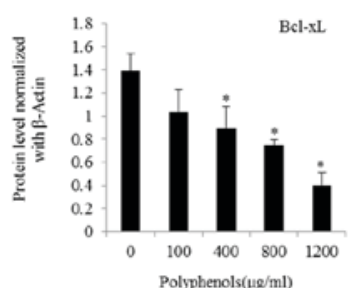
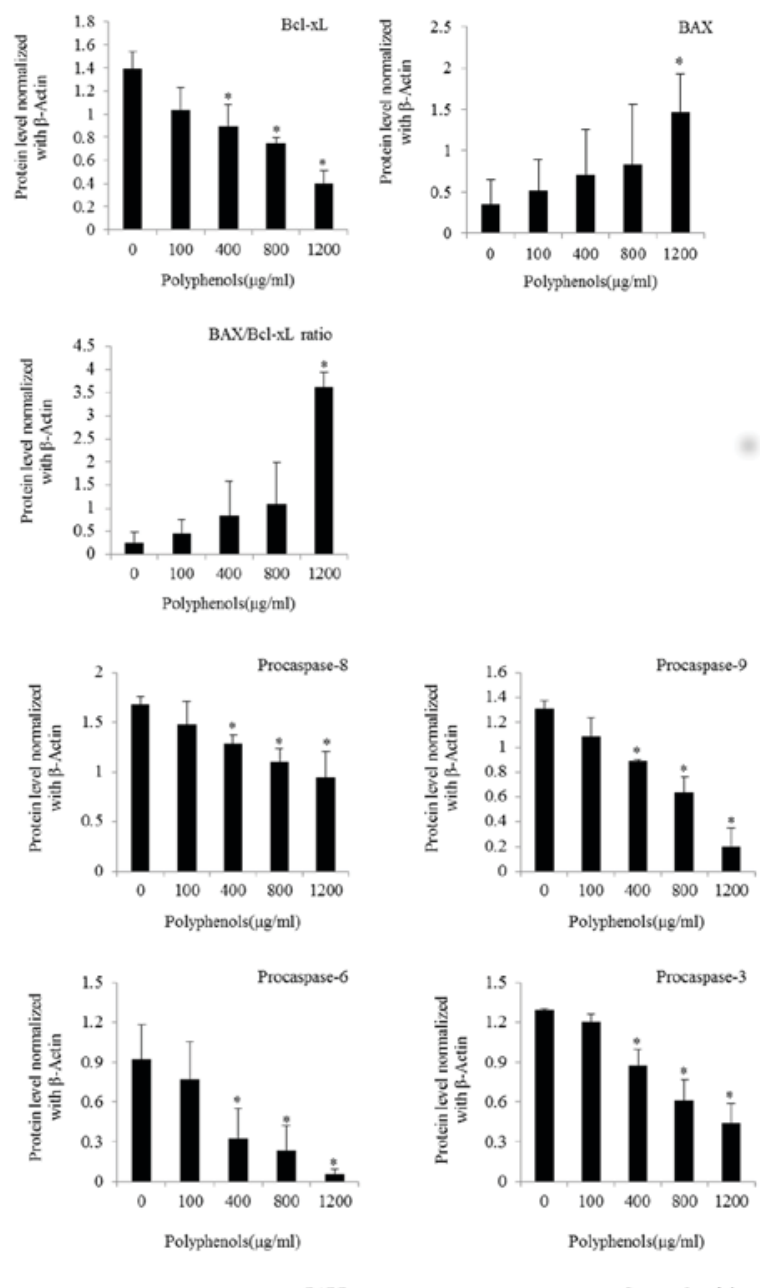

Polyphenols $(\mu g / \mathrm{ml})$
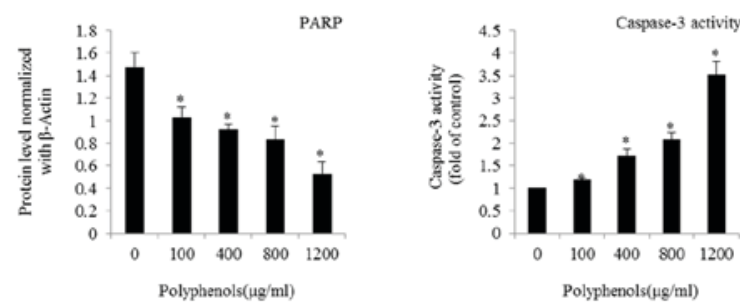

p-AKT

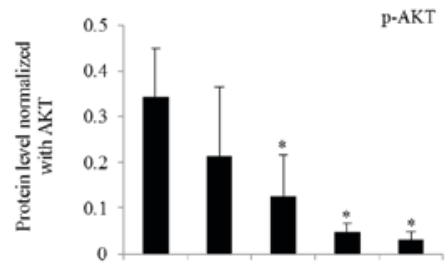

Figure 5. Effect of polyphenolic compounds on apoptosis-associated protein (Bcl-xL, BAX, caspases, PARP and AKT) expression levels and caspase-3 activity in A549 cells. The cells were treated with polyphenolic compounds $(0,100,400,800$ and 1,200 $\mu \mathrm{g} / \mathrm{ml})$ for $24 \mathrm{~h}$. (A) Whole cell lysates were subjected to SDS-PAGE and analyzed Bcl-xl and Bax by western blotting. (B) Densitometry analysis of the effect of flavonoids on the expression levels of apoptosis-associated proteins and caspase-3 activity is depicted. (C) p-AKT was normalized to the respective total AKT, and is presented relative to the value for the untreated control cells. The data are presented as the mean \pm standard deviation of triplicate independent experiments. "P<0.05 compared with the control. Bcl-xL, B-cell lymphoma-extra large; BAX, Bcl-2-associated x-protein; PARP, poly-(ADP-ribose) polymerase; AKT, protein kinase B; SDS-PAGE, sodium dodecyl sulfate polyacrylamide gel electrophoresis; p-AKT, phosphorylated AKT.

cycle arrest and increases the effects of radiation and certain chemotherapeutic agents in numerous types of cancer (34-36). Cell cycle progression may be affected by AKT through the suppression of the cyclin-dependent kinase inhibitor p21 (WAF1/CIP1) (37). In addition, the upregulation of p-AKT serves to provide cells with a survival signal that allows them to resist apoptotic stimuli, by inhibiting specific pro-apoptotic proteins (38). Clinical studies have demonstrated that AKT activation is a common feature of numerous types of cancer, and that it correlates with poor prognosis (39). To evaluate 
the regulation of AKT by polyphenolic compounds, p-AKT was investigated in A549 cells. The results demonstrated that polyphenolic compounds suppressed the expression levels of p-AKT in a dose-dependent manner (Fig. 5C). These results indicate that the downregulation of $\mathrm{p}$-AKT by polyphenolic compounds triggered apoptosis through the upregulation of pro-apoptotic proteins.

In conclusion, the results of the present study demonstrate the anticancer properties of polyphenolic compounds isolated from L. japonica T. in A549 cells. The polyphenolic compounds induced apoptosis in A549 cells by downregulating certain pro-caspases (caspase-3, -6, -8 and -9) and PARP, and increasing the Bax/Bcl-xL ratio, caspase- 3 activity, MMP dysfunction and the dephosphorylation of AKT, inducing apoptosis by a mitochondria-dependent signaling pathway. Flow cytometry demonstrated that polyphenolic compounds are able to induce apoptosis by increasing the $\mathrm{sub}-\mathrm{G}_{1}$ cell population, which was also indicated by FITC-Annexin V double staining in A549 cells. The results suggest that the polyphenolic compounds isolated from L.japonica $T$. must be evaluated in further studies as a potential therapeutic agent for the treatment of human lung cancer.

\section{Acknowledgements}

This study was supported by the National Research Foundation of Korea funded by the Ministry of Science, ICT and Future Planning (grant no. 2012M3A9B8019303) and a grant (no. K16281) from the Korea Institute of Oriental Medicine funded by the Ministry of Education, Science and Technology (MEST), Republic of Korea.

\section{References}

1. Jemal A, Tiwari RC, Murray T, Ghafoor A, Samuels A, Ward E, Feuer EJ and Thun MJ; American Cancer Society: Cancer statistics, 2004. CA Cancer J Clin 54: 8-29, 2004.

2. Kwon SH, Hong SI, Kim JA, Jung YH, Kim SY, Kim HC, Lee SY and Jang CG: The neuroprotective effects of lonicera japonica THUNB. against hydrogen peroxide-induced apoptosis via phosphorylation of MAPKs and PI3K/akt in SH-SY5Y cells. Food Chem Toxicol 49: 1011-1019, 2011.

3. Chen K, Plumb GW, Bennett RN and Bao Y: Antioxidant activities of extracts from five anti-viral medicinal plants J Ethnopharmacol 96: 201-205, 2005.

4. Yue PY, Leung EP, Mak NK and Wong RN: A simplified method for quantifying cell migration/wound healing in 96-well plates J Biomol Screen 15: 427-433, 2010.

5. Lindsten T, Ross AJ, King A, Zong WX, Rathmell JC, Shiels HA, Ulrich E, Waymire KG, Mahar P, Frauwirth K, et al: The combined functions of proapoptotic bcl-2 family members bak and bax are essential for normal development of multiple tissues. Mol Cell 6: 1389-1399, 2000

6. Fong KM, Sekido Y, Gazdar AF and Minna JD: Lung cancer. 9: Molecular biology of lung cancer: Clinical implications. Thorax 58: 892-900, 2003.

7. Ridge CA, McErlean AM and Ginsberg MS: Epidemiology of lung cancer. Semin Intervent Radiol 30: 93-98, 2013.

8. Oltvai ZN, Milliman CL and Korsmeyer SJ: Bcl-2 heterodimerizes in vivo with a conserved homolog, bax, that accelerates programmed cell death. Cell 74: 609-619, 1993.

9. Los M, Mozoluk M, Ferrari D, Stepczynska A, Stroh C, Renz A, Herceg Z, Wang ZQ and Schulze-Osthoff K: Activation and caspase-mediated inhibition of PARP: A molecular switch between fibroblast necrosis and apoptosis in death receptor signaling. Mol Biol Cell 13: 978-988, 2002.

10. Newman DJ and Cragg GM: Natural products as sources of new drugs over the 30 years from 1981 to 2010. J Nat Prod 75: 311-335, 2012.
11. YipEC, Chan AS, Pang H, Tam YK and Wong YH: Protocatechuic acid induces cell death in HepG2 hepatocellular carcinoma cells through a c-Jun N-terminal kinase-dependent mechanism. Cell Biol Toxicol 22: 293-302, 2006.

12. Pak JH, Choi WH, Lee HM, Joo WD, Kim JH, Kim YT, Kim YM and Nam JH: Peroxiredoxin 6 overexpression attenuates cisplatin-induced apoptosis in human ovarian cancer cells. Cancer Invest 29: 21-28, 2011.

13. Lin Y, Shi R, Wang X and Shen HM: Luteolin, a flavonoid with potential for cancer prevention and therapy. Curr Cancer Drug Targets 8: 634-646, 2008.

14. Choi EJ and Ahn WS: Kaempferol induced the apoptosis via cell cycle arrest in human breast cancer MDA-MB-453 cells. Nutr Res Pract 2: 322-325, 2008

15. Markiewski MM and Lambris JD: The role of complement in inflammatory diseases from behind the scenes into the spotlight. Am J Pathol 171: 715-727, 2007.

16. Elmore S: Apoptosis: A review of programmed cell death. Toxicol Pathol 35: 495-516, 2007.

17. Compagno M, Lim WK, Grunn A, Nandula SV, Brahmachary M, Shen Q, Bertoni F, Ponzoni M, Scandurra M, Califano A, et al: Mutations of multiple genes cause deregulation of NF-kappaB in diffuse large B-cell lymphoma. Nature 459: 717-721, 2009.

18. Findley HW, Gu L, Yeager AM and Zhou M: Expression and regulation of bcl-2, bcl-xl, and bax correlate with p53 status and sensitivity to apoptosis in childhood acute lymphoblastic leukemia. Blood 89: 2986-2993, 1997.

19. Ha YM, Park MK, Kim HJ, Seo HG, Lee JH and Chang KC: High concentrations of ascorbic acid induces apoptosis of human gastric cancer cell by p38-MAP kinase-dependent up-regulation of transferrin receptor. Cancer Lett 277: 48-54, 2009.

20. Silbergeld EK: Facilitative mechanisms of lead as a carcinogen. Mutat Res 533: 121-133, 2003.

21. Manning BD and Cantley LC: AKT/PKB signaling: Navigating downstream. Cell 129: 1261-1274, 2007.

22. Park HS, Park KI, Lee DH, Kang SR, Nagappan A, Kim JA, Kim EH, Lee WS, Shin SC, Hah YS and Kim GS: Polyphenolic extract isolated from Korean Lonicera japonica Thunb. induce G2/M cell cycle arrest and apoptosis in HepG2 cells: Involvements of PI3K/Akt and MAPKs. Food Chem Toxicol 50: 2407-2416, 2012.

23. Park KI, Park HS, Nagappan A, Hong GE, Lee DH, Kang SR, Kim JA, Zhang J, Kim EH, Lee WS, et al: Induction of the cell cycle arrest and apoptosis by flavonoids isolated from Korean Citrus aurantium L. In non-small-cell lung cancer cells. Food Chem 135: 2728-2735, 2012.

24. Park KI, Kang SR, Park HS, Lee DH, Nagappan A, Kim JA, Shin SC, Kim EH, Lee WS, Chung HJ, et al: Regulation of Proinflammatory Mediators via $N F-\kappa B$ and p38 MAPK-Dependent Mechanisms in RAW 264.7 Macrophages by Polyphenol Components Isolated from Korea Lonicera japonica THUNB. Evid-Based Compl Alt Med 2012: 10, 2012.

25. Pan SY, Litscher G, Gao SH, Zhou SF, Yu ZL, Chen HQ, Zhang SF, Tang MK, Sun JN and Ko KM: Historical perspective of traditional indigenous medical practices: The current renaissance and conservation of herbal resources. Evid Based Complement Alternat Med 2014: 525340, 2014.

26. Carocho $M$ and Ferreira IC: The role of phenolic compounds in the fight against cancer-a review. Anticancer Agents Med Chem 13: 1236-1258, 2013.

27. Kim H, Bae S, Yu Y, Kim Y, Kim HR, Hwang YI, Kang JS and Lee WJ: The analysis of vitamin $\mathrm{C}$ concentration in organs of gulo(-/-) mice upon vitamin $\mathrm{C}$ withdrawal. Immune Netw 12: 18-26, 2012.

28. Mcllwain DR, Berger T and Mak TW: Caspase functions in cell death and disease. Cold Spring Harb Perspect Biol 5: a008656, 2013.

29. Xinghua L, Bo Z, Yan G, Lei W, Changyao W, Qi L, Lin Y, Kaixiong T, Guobin $\mathrm{W}$ and Jianying $\mathrm{C}$ : The overexpression of AP-4 as a prognostic indicator for gastric carcinoma. Med Oncol 29: 871-877, 2012.

30. Jung KW, Park S, Won YJ, Kong HJ, Lee JY, Seo HG and Lee JS: Prediction of cancer incidence and mortality in korea, 2012. Cancer Res Treat 44: 25-31, 2012.

31. Liu X, Zhang B, Guo Y, Liang Q, Wu C, Wu L, Tao K, Wang G and Chen J: Down-regulation of AP-4 inhibits proliferation, induces cell cycle arrest and promotes apoptosis in human gastric cancer cells. PLoS One 7: e37096, 2012.

32. Kale A, Gawande S and Kotwal S: Cancer phytotherapeutics: Role for flavonoids at the cellular level. Phytother Res 22: 567-577, 2008. 
33. Jung KH, Ha E, Kim MJ, Won HJ, Zheng LT, Kim HK, Hong SJ, Chung JH and Yim SV: Suppressive effects of nitric oxide (NO) production and inducible nitric oxide synthase (iNOS) expression by citrus reticulata extract in RAW 264.7 macrophage cells. Food Chem Toxicol 45: 1545-1550, 2007.

34. Kelley JR and Duggan JM: Gastric cancer epidemiology and risk factors. J Clin Epidemiol 56: 1-9, 2003.

35. Ha GH, Lee SU, Kang DG, Ha NY, Kim SH, Kim J, Bae JM, Kim JW and Lee CW: Proteome analysis of human stomach tissue: Separation of soluble proteins by two-dimensional polyacrylamide gel electrophoresis and identification by mass spectrometry. Electrophoresis 23: 2513-2524, 2002.

36. Lin YM, Chen YR, Lin JR, Wang WJ, Inoko A, Inagaki M, Wu YC and Chen RH: eIF3k regulates apoptosis in epithelial cells by releasing caspase 3 from keratin-containing inclusions. J Cell Sci 121: 2382-2393, 2008.
37. Shen SM, Yu Y, Wu YL, Cheng JK, Wang LS and Chen GQ: Downregulation of ANP32B, a novel substrate of caspase-3, enhances caspase-3 activation and apoptosis induction in myeloid leukemic cells. Carcinogenesis 31: 419-426, 2010.

38. Hahne M, Kataoka T, Schröter M, Hofmann K, Irmler M, Bodmer JL, Schneider P, Bornand T, Holler N, French LE, et al: APRIL, a new ligand of the tumor necrosis factor family, stimulates tumor cell growth. J Exp Med 188: 1185-1190, 1998.

39. Pal SK, Reckamp K, Yu H and Figlin RA: Akt inhibitors in clinical development for the treatment of cancer. Expert Opin Investig Drugs 19: 1355-1366, 2010. 